\title{
Okullarda Örgütsel Sinizm ile Örgütsel İkiyüzlülük Arasındaki İlişkinin İncelenmesi
}

\author{
DOI: 10.26466/opus.906933
}

\author{
Ahmet Göçen* - Mehmet Uzun** - Ahmet Kaya*** \\ * Doç. Dr., Harran Üniversitesi, Şanlıurfa/Türkiye \\ E-Posta: \\ ahmetgocen35@gmail.com \\ ORCID: $\underline{0000-0002-9376-2084}$ \\ ** Öğretmen, MEB, Kahramanmaraş /Türkiye \\ E-Posta: mehmetuzun461@hotmail.com \\ ORCID: $\underline{0000-0003-2786-5533}$ \\ *** Doç.Dr., Kahramanmaraş Sütçü İmam Üniversitesi, Kahramanmaraş /Türkiye \\ E-Posta: akaya574@hotmail.com \\ ORCID: $\quad \underline{0000-0001-8899-9178}$
}

Öz

Okullarda öğretmen motivasyonu, eğitsel başarı ve sağllklı kurum kültürü için önemli şartlardan birisidir. Eğitim kurumlarnda görülebilen örgütsel sinizm ve ikiyüzlülük davranıslar öğretmen motivasyonu ve okul çıktıları üzerinde olumsuz etkilere sebep olabilmektedir. Bu çalşmanın amacı okullarda algllanan örgütsel sinizm ve örgütsel ikiyüzlülük boyutları arasındaki ilişkiyi ele almak ve bu olgulara ilişkin öğretmen algılarmı cinsiyet, okul kademesi ve hizmet süresi gibi farkl değişkenlere göre incelemektir. Temel olarak iki kavram arasındaki ilişkilerin yönünü veya derecesini tespit etmeyi amaçlayan ilişkisel araştırma desenli bu nicel çalş̧mada yapısal eşitlik modellemesi kullanılarak yol analizi yapılmıştır. 2020-2021 eğitim ve öğretim yılı bahar döneminde ölçme araçları yardımıyla 378 öğretmenden veri toplanmış ve ilgili varsayımlarm kontrolü sonrasında analizler yapılmıştır. Çalışma sonucunda öğretmenlerin, okullara ilişkin örgütsel sinizm ve ikiyüzlülük algllarmmn genel olarak düşük düzeyde olduğu sonucuna ulaşılmıştır. Hizmet süresi değişkenine ve cinsiyete göre bazı alt boyutlarda gruplar arası anlaml fark saptanmıştır. Çalı̧mada örgütsel sinizm (bilişsel, duyuşsal, davranışsal boyutları) ve örgütsel ikiyüzlülük (içyapı ve çeore arasındaki uyum, uygulamadaki tutarsızlklar, sözlerin tutulması boyutları) arasında pozitif yönde anlaml ilişkilerin bulunduğu sonucuna ulaşılmıştır. Yol analizi sonucunda örgütsel ikiyüzlülü̈̆̈̈̈n uygulamalardaki tutarsızlklar boyutunun örgütsel sinizmin bilişsel, duyuşsal ve davranışsal boyutlarnm anlamlı yordayıcısı olduğu görülmüş̧tür. Diğer çalışmalar okullarda görülen uygulamalardaki tutarsızlklar özelinde örgütsel sinizmin oluşma sürecini inceleyebilir.

Anahtar Kelimeler: Eğitim Yönetimi, Sinizm, İkiyüzlülük, Okul, Öğretmen. 


\title{
Examining the Relationship between Organizational Cynicism and Organizational Hypocrisy in Schools
}

\begin{abstract}
Teacher motivation in schools is one of the critical requisites for educational success and a healthy organizational climate. Organizational cynicism and hypocrisy can adversely affect teacher motivation and school outcomes. The goal of this study is to determine the relationship between the sub-dimensions of organizational cynicism and organizational hypocrisy and examine these concepts in terms of different variables such as gender, school type, and length of service. In this correlational study, which aims to determine the relationship among the concepts, a path analysis was conducted using structural equation modeling. Researchers collected data from 378 teachers in the spring semester of 2020-2021 with the assistance of scales. As a result of the study, the teachers' perceptions of organizational cynicism and hypocrisy were found to be at a low level. The study found significant differences between the groups in some sub-dimensions according to the teachers' length of service and gender. The researchers concluded that there were significant positive relationships between organizational cynicism (the cognitive, affective, and behavioral dimensions) and organizational hypocrisy (the sub-dimensions of putting words into practice, compliance between the school's internal structure and the environment, and inconsistency in their practices). As a result of the path analysis, it was seen that inconsistency in practices, a dimension of organizational hypocrisy, was a significant predictor of cognitive, affective, and behavioral dimensions of organizational cynicism. Future studies could examine the formation of organizational cynicism resulting from the inconsistencies of practices in schools.
\end{abstract}

Keywords: Educational Administration, Cynicism, Hypocrisy, School, Teacher. 


\section{Giriş}

Öğretmenlik mesleğinin stresli doğası gereği öğretmenler tükenmişlik ve bıkkınlık gibi duygular yaşayabilmektedir (Sak, 2018). Bu sorunun sebepleri olarak öğretmen iş doyumunun düşüklüğü, okul içi empatik iletişimin ve destek sistemlerin eksikliği gibi nedenler öncelikli olarak sıralanabilir (Göçen, 2019). Diğer kurumlar gibi okulların da kurumsal performansların daha iyi hale getirmek için çalışanların çalışma koşullarını, iş performanslarını ve işe ilişkin memnuniyetlerini iyileştirmeleri (Acaray ve Yildirim, 2017); bunun yanı sıra öğretmen motivasyonunu düşüren etkenleri ortadan kaldırmaları gerekmektedir. Nitekim işinden memnun olan öğretmenler sinizm ve tükenmişlik gibi olumsuz olgulardan kendilerini koruyabilmektedir (Sak, 2018). Tam tersi durumda ise toplumun geleceğini inşa edecek mimarları yetiştiren okulların örgütsel amaçlarını gerçekleştirmede sorunlar yaşayabileceği söylenebilir. Okullar bu açıdan öğretmen motivasyonunu ve iş doyumunu düşüren başta örgütsel sinizm ve örgütsel ikiyüzlülük gibi sorunları ortadan kaldıracak yönetimsel adımları hayata geçirmelidir. Bu nedenle bu çalışmada okullarda algılanan örgütsel sinizm ve örgütsel ikiyüzlülük olguları arasındaki ilişki ele alınmış ve kavramlar eğitim örgütleri açısından farklı değişkenlere göre irdelenmiştir.

\section{Örgütsel Sinizm}

Sinizm en genel anlamında kişinin bağlı olduğu örgüte karşı olumsuz ve güvensiz bir tutum geliştirmesidir. Bu açıdan örgütsel sinizm, çalışanlar kurumlarına güven duymadıklarında veya çalışma gruplarına güvenilemeyeceğini hissettiklerinde ortaya çıkar (Durrah vd., 2019). Çalışanın örgüte karşı olumsuz yaklaşımı olarak tanımlanan örgütsel sinizm 3 boyutta ele alınabilir: çalışanın (1) örgütüne ilişkin örgütsel bütünlük (integrity) eksikliği duygusunu taşıması ile (2) örgüte karşı olumsuz tutumları ve (3) örgüte karşı küçük düşürücü ve eleştirel davranışlarından oluşur (Dean vd., 1998).

Örgütsel sinizmin çalışan performansı üzerinde olumsuz etkilerinin olduğu bilinmektedir (Acaray ve Yildirim, 2017; Durrah vd., 2019). Örgütsel sinizme neden olan faktörlerin düzeltilemediği bir kurumda çalışanlar bu his ile örgüte zarar verecek davranışlara yönelebilirler (Gedik ve Üstüner, 2019). Örgütte sinizmin oluşması, çalışanlarda tükenmişlik ve güvensizliğe yol açan 
durumlar ile başlar. Akar (2018, s.2100), yaptı̆̆ kapsamlı bir alanyazın taraması ışı̆̆ında "iş yükü, örgütsel adalet, örgütsel destek, mobbing, etik liderlik, kayırmacllık, iş güvencesi, örgütsel stres, psikolojik sözleşme ihlali, denetim kaygısı, politik ayrımclık, örgütsel sessizlik, örgüt kültürü, örgütsel iletişim, örgütsel güven, örgütsel dışlanma ve yabancılaşma" gibi değişkenlerin eğitim kurumlarında örgütsel sinizm yaşanıp yaşanmamasında önemli etkiye sahip olduğunu ifade etmiştir.

Örgütsel sinizm; alanyazında genel olarak bilişsel, duyuşsal ve davranışsal sinizm olmak üzere 3 boyutta ele alınmaktadır (Dean vd., 1998). Akar'a (2018, s.2100) göre bilişsel sinizmde, çalışanlar örgütsel bütünlügü oluşturan ilkelerden olan dürüstlük, adalet, açıklık ve samimiyet gibi özelliklerden örgütün yoksun olduğu inancını taşımaktadır. Duyuşsal sinizmde, çalışanlar örgüte ilişkin duygusal açıdan olumsuz hislere sahiptir. Davranışsal sinizmde ise çalışanlar olumsuz tutumlarını davranışa dönüştürmekte ve samimiyetten, açıklıktan ve dürüstlükten uzak, alaycı, karamsar, yapmacık, küçümseyici ve ukala tavırlar sergilemektedir.

\section{Örgütsel İkiyüzlülük}

İnsanlar için iletişim süreci çift taraflıdır ve bu süreçteki bilgi paylaşımının derecesi tarafların birbirine karşı duyduğu güven duygusuna göre oluşur. Bir kurumda bireylerden özü ve sözü bir olacak şekilde söylemleri doğrultusunda hareket etmeleri beklenir, fakat bu beklentinin aksine çalışanların ikiyüzlü davranışlar sergiledikleri durumlar ortaya çıkabilir (Çimen ve Karadağ, 2021). Kurumda ikiyüzlülük yöneticilerin ve çalışma arkadaşlarının sahip olmadıkları duygu, düşünce, erdem, değer ve özelliklere sahipmiş gibi kendilerini başkalarına olduklarından farklı şekilde yansıtmalarını içeren bir kavramdır (Konan ve Taşdemir, 2019). Eğitim kurumları için ikiyüzlülük, okuldaki kişilerin sahip oldukları tutarsız değerler, çıkarlar, fikirler ve eylemler anlamına gelmektedir, okullarda örgütsel ikiyüzlülük kararların kolayca söylendiği; fakat yerine getirilmediği zamanlar ortaya çıkmaktadır (Kılıçoğlu, 2017, s.489).

Kuruluşlar, çevreden meşruiyet ve destek kazanmak için konuşmalarında, kararlarında veya çalışmalarında tutarsız eylemlere başvurabilir (Kıllçoğlu vd., 2019). Örgütsel ikiyüzlülük genelde çkar gruplarına atfedilecek bir 
durum gibi görünse de eğitim kurumlarında da bu duruma şahit olunmaktadır; okullar çevre baskılarına maruz kalınca ve diğer okullar ile bir yarış ortamına sürüklenince kendisinde var olmayan durumları varmış gibi göstermeye çalışabilmektedir (Kahveci vd., 2019). Maalesef söylediklerinin aksine başka bir şeyler yaparken görülen kurumların örnekleri günümüzde giderek artmaktadır (Higgins vd., 2020). Bu açıdan ikiyüzlülük örgütler için adeta affedilmez bir günah (Shklar, 1984, s.45) olup bu durum örgütsel değer yitimi olarak adlandırılabilir. Bazen sistemin kendisi de ikiyüzlülüğü doğuran bir sonuca yol açabilmektedir (Kılıçoğlu vd., 2019). Bu durum özellikle idareci ve öğretmenler arasında güvensizliği doğurabileceği için sağlıklı kurum atmosferine ciddi bir tehdittir. Nitekim örgütsel ikiyüzlülük, olumlu bir çalışma ortamına izin vermez ve örgütsel güveni azaltır (Kahveci vd., 2019).

Örgütsel ikiyüzlülük olumsuz bileşenlerden oluşur: olumsuz konuşmalar, kararlar ve eylemlerdeki tutarsızlıklar; bir kuruluşun çevrenin normlarını ve değerlerini yansitmadaki yetersizlikler, hedeflerini ve misyonunu yerine getirememek vb. (Kılıçoğlu vd., 2019). Örgütsel ikiyüzlülük Wagner ve arkadaşlarına (2020) göre 3 farklı kapsamda algılanmaktadır: Ahlaki İkiyüzlülük, Davranışsal İkiyüzlülük, İkiyüzlülük Nitelikleri. Yazarlara göre ahlaki ikiyüzlülük, bir kurumun olduğundan daha erdemli görünmeye çalıştığı hakkındaki inancl; davranışsal ikiyüzlülük kurumun gösterdiği eylemlerin, beyanlarıyla tutarsız olduğu hakkındaki inancı ve ikiyüzlülük nitelikleri de kurumun ikiyüzlü doğası olduğu hakkındaki inancı içerir. Örgütsel ikiyüzlülük, kişilerin algılarında özetle bu şekilde ortaya çıkmakta ve organizasyona ilişkin olumsuz insan görüşlerinden oluşmaktadır.

\section{Örgütsel Sinizm ve Örgütsel İkiyüzlülük Arasındaki İlişki}

Örgütsel sinizm ve örgütsel ikiyüzlülük arasında anlamlı bir ilişki bulunmaktadır (Kılıçoğlu vd., 2019). İki olgunun işyerinde ve kişilerde birçok olumsuz sonuçla ilişkili olduğu alanyazında daha önce yapılmış çalışmalarda da ifade edilmektedir (Abraham, 2000; Kılıçoğlu vd., 2019). Nitekim örgütsel ikiyüzlülük, bireylerin örgüt çalışanlarına ne ölçüde güvendiklerini etkilediği kadar çalışanların örgütleri hakkında ne kadar sinizme sahip olduklarını da etkiler (Kılıçoğlu vd., 2020). Öte yandan ikiyüzlülüğü; gerçek dışı ve/veya haksız muamele, dürüst olmamak, sahtekârlık ve/veya samimiyetsizlik gibi kavramlar kapsamında değerlendirilebileceğini belirten Naus ve arkadaşlarına 
(2007) göre bu davranışlar nedeniyle organizasyon hakkında oluşan olumsuz hava örgütsel sinizme yol açabilir. Bu açıdan da bakıldığında alanyazınla tutarlı olarak ikiyüzlülüğün sinizmin bir yordayıcısı olduğu ifade edilebilir. Bu bilgilerden hareketle örgütsel ikiyüzlülügün okullarda sinizmin oluşmasında etkisi olabileceği düşünülmüş ve olgular arası ilişkiler incelenmesine karar verilmiştir. Ayrıca ilgili kavramlara ilişkin öğretmen algıları cinsiyet, hizmet süresi vb. bağımsız değişkenlere göre analiz edilmiştir.

\section{Yöntem}

Bu bölümde, araştırmanın modeli, evren ve örneklemi, veri toplamada kullanılan ölçme araçları ve verilerin analizinde kullanılan istatistik teknikleriyle ilgili bilgilere yer verilmiştir.

\section{Araştırmanın Modeli}

Öğretmenlerin örgütsel sinizm tutumları ve örgütsel ikiyüzlülük algıları arasındaki ilişkinin incelendiği bu araştırma, nicel bir çalışma olup değişkenler arasındaki ilişkileri, birlikte değişimi ve ilişki düzeyini tespit etmeyi amaçlayan ilişkisel araştırma yöntemine göre yapılandırılmıştır (Akbay, 2019). Çalışmada ilgili kavramlar arası ilişkiler dışında öğretmenlerin örgütsel sinizm ve örgütsel ikiyüzlülük algılarının düzeyleri betimsel olarak sunulmuş ve bu iki değişkene ait boyutların öğretmenlerin bazı demografik özelliklerine göre farklılaşma durumları belirlenmeye çalışılmıştır. Değişkenler arasındaki ilişkileri tek bir modelde inceleyebilmek amacıyla yapısal eşitlik modellemesi kullanılarak yol analizi tercih edilmiştir.

\section{Örneklem}

Araştırma evrenini, 2020-2021 Eğitim-Öğretim yılında Kahramanmaraş ili merkez ilçelerinde (Dulkadiroğlu ve Onikişubat) bulunan kamu anaokulu, ilkokul, ortaokul ve liselerinde görev yapan toplam 8957 öğretmen oluşturmaktadır. Araştırmanın örneklemi için gereken büyüklügün \%95 güven düzeyi için 368 kişi olduğu belirlenmiştir. Pandemi nedeniyle okullara birebir ulaşmanın zorluğundan dolayı online bir form oluşturulmuş ve iki ilçedeki 
birçok idareci/öğretmenin üye olduğu gruplara çalışma linkleri olarak atılmıştır. Bu şekilde 394 öğretmen çalışmada gönüllü şekilde yer almıştır. Toplanan ölçme araçlarından veri analizine uygun olmayan 16 tanesi çıkarılarak geriye kalan 378 tanesi ile analizler yapılmıştır. Araştırma örneklemine dâhil edilen katılımcıların \%60.6'sını ( $n=229)$ kadınlar, \%39.4'ünü $(n=149)$ erkekler oluşturmaktadır. Katılımcıların \%46.3'ü ( $\mathrm{n}=175)$ 1-5 yıl arasında, \%32'si (n=121) 6-10 yıl arasında, \%12.7'si $(n=48)$ 11-19 yıl arasinda ve \%9'u (n=34) 20 yıl ve üzeri hizmet süresine sahiptir. Katılımciların \%11.6's1 $(\mathrm{n}=44)$ anaokullarında, \%32.8'i (n=124) ilkokullarda, \%37.3'ü (n=141) ortaokullarda ve $\% 18.3^{\prime} \ddot{\mathrm{u}}(\mathrm{n}=69)$ ise liselerde görev yapmaktadır.

\section{Veri Toplama Araçları}

Araştırmada öğretmenlerin örgütsel sinizm tutumlarını belirlemek için "Örgütsel Sinizm Ölçeği", örgütsel ikiyüzlülük algılarını belirlemek için ise "Örgütsel İkiyüzlülük Ölçeği” kullanılmıştır. Veri toplama araçlarının araştırmada kullanılabilmesi için araştırmacılardan gerekli izinler e-posta yoluyla alınmıştır.

Brandes, Dharwadkar ve Dean (1999) tarafından geliştirilen "Örgütsel Sinizm" ölçeği Kalağan (2009) tarafından Türkçeye uyarlanmıştır. 13 maddeden ve üç alt boyuttan (Bilişsel, Duyuşsal, Davranışsal) oluşan ölçek, katılımc1ların örgütsel sinizm tutumlarını belirlemek için "1=Hiç katılmıyorum (1.001.80) ile 5=Tamamen katılıyorum (4.21-5.00)" aralığında olmak üzere "Beşli Likert" şeklinde derecelendirilmiştir. Kalağan (2009) yapmış olduğu güvenirlik analizi sonucunda ölçeğin tamamı için Cronbach Alpha katsayısını 93 olarak bulurken; bilişsel, duyuşsal ve davranışsal sinizm alt boyutları için güvenirlik katsayılarını sırasıyla $.91, .95$ ve .87 olarak hesaplamıştır. Bu araştırma da ise ölçeğin geneli için Cronbach Alpha katsayısı .93 olarak bulunurken, alt boyutları için güvenirlik katsayıları sırasıyla $.93, .96$ ve .80 olarak bulunmuştur. Örgütsel Sinizm Ölçeğinin 3 faktörlü yapısını doğrulamak amacıyla bu araştırma kapsamında yapısal eşitlik modeli kullanılarak Doğrulayıcı Faktör Analizi (DFA) yapılmıştır. Yapısal eşitlik modeli analizlerinde uyulması gereken temel işlem basamaklarından biri olan model uyumunun değerlendirilmesinde (Çokluk, Şekercioğlu ve Büyüköztürk, 2014); $\chi^{2} / s d$, CFI, TLI, RMSEA ve SRMR değerleri kullanılmıştır (Kline, 2019). DFA sonucunda madde faktör yük değerleri .51 ile .90 aralığında ve manidar bulunmuştur. 
Ölçeğin üç boyutlu yapısının doğrulandığı ve modele ait uyum indekslerinin $\left(\chi^{2} / \mathrm{sd}=3.30, \mathrm{CFI}=.96, \mathrm{TLI}=.95, \mathrm{RMSEA}=.07, \mathrm{SRMR}=.04\right)$ iyi uyum düzeylerinde olduğu görülmüş̧ür (Çelik ve Yılmaz, 2014; Sümer, 2000; Tabachnick ve Fidell, 2001).

“Örgütsel İkiyüzlülük Ölçeği” Kılıçoğlu, Yılmaz-Kılıçoğlu ve Karadağ (2019) tarafından geliştirilmiştir. 17 maddeden ve üç alt boyuttan (İçyap ve Çevre Arasındaki Uyum, Uygulamalardaki Tutarsızlıklar, Sözlerin Tutulması) oluşan ölçek, katılımcıların örgütsel ikiyüzlülük algıların belirlemek için " $1=\mathrm{Ke}-$ sinlikle katılmiyorum (1.00-1.80) ile 5=Kesinlikle katiliyorum (4.21-5.00)" aralığında olmak üzere "Beşli Likert" şeklinde derecelendirilmiştir. İçyapı ve çevre arasındaki uyum ve sözlerin tutulması boyutlarını oluşturan maddeler ölçek geliştiricilerin önerileri doğrultusunda yorumlamayı kolaylaştırması bakımından ters kodlanarak analizlere dâhil edilmiştir. Boyutlara ilişkin puanların düşük olması içyapı ve çevre arasındaki uyumun yüksek olduğunu, uygulamalarda tutarsızlıkların bulunmadığını ve sözlerin tutulduğu şeklinde yorumlanmaktadır. Araştırmacılar, yapmış oldukları güvenirlik analizi sonucunda; içyapı ve çevre arasındaki uyum, uygulamalardaki tutarsızlıklar ve sözlerin tutulması alt boyutları için güvenirlik katsayılarını sırasıyla .87, .74 ve .86 olarak hesaplamıştır. Bu araştırma da ise ölçeğin geneli için Cronbach Alpha katsayısı .94 olarak bulunurken, alt boyutları için güvenirlik katsayıları sırasıyla .88 , .87 ve .91 olarak bulunmuştur. Ölçeğin 3 faktörlü yapısını doğrulamak amacıyla Doğrulayıcı Faktör Analizi (DFA) yapılmıştır. DFA sonucunda madde faktör yük değerlerinin .48 ile .86 aralığında olduğu, ölçeğin üç boyutlu yapısının doğrulandığı ve modele ait uyum indekslerinin iyi uyum düzeylerinde olduğu görülmüştür $\left(\chi^{2} / \mathrm{sd}=2.97, \mathrm{CFI}=.95, \mathrm{TLI}=.94\right.$, RMSEA=.07, SRMR=.04).

\section{Verilerin Toplanmas1}

Araştırma kapsamının, veri toplama yönteminin ve kullanılacak ölçme araçlarının etik açıdan uygunluğuna ilişkin olarak Harran Üniversitesi Sosyal ve Beşeri Bilimler Etik Kurulu'ndan etik kurul onayı alınmıştır. Elektronik ortama aktarılan ölçme araçları birçok okul müdürünün üye olduğu sosyal medya grupları aracilığıyla öğretmenlere ulaştırılmıştır. Dönütler istenilen sayıya ulaşınca ölçek kabulü sonlandırılmıştır. 


\section{Verilerin Analizi}

Araştırma verilerinin analizinde kullanılacak değişkenlerin tek değişkenli normallik dağılımlarını belirlemede başta çarpıklık/basıklık katsayıları (+1 ile -1 arasında olması) olmak üzere histogram/Q-Q Plot grafikleri incelenmiştir (Büyüköztürk, 2017; Seçer, 2013). İlgili verilerin incelenmesi sonucunda verilerin normal dağılıma göre parametrik yöntemler ile devam edilmesine karar verilmiştir. Veri analizlerinde değişkenlere ilişkin puanların aritmetik ortalama ve standart sapma değerleri belirlenmiş, alınan puanların demografik değişkenler bakımından farklılaşma durumunu belirlemek t-Testi ve Tek Yönlü Varyans Analizi (ANOVA) testi kullanılmıştır. Anlamlı bulunan F değerinde fark olan grupları belirlemede Post Hoc testlerinden yararlanılmıştır. Değişkenler arasındaki ilişkiyi belirlemek için korelasyon analizi kullanılmıştır. Bağımsız değişkenlerin bağımlı değişkenler üzerindeki yordayıcılık durumlarını belirlemek için mPlus 8 paket programı kullanılarak yol analizi kullanılmıştır. Yol analizi, "araştırmacının bir değişkenden diğerine doğrudan ve dolaylı etkileri kestirmesine izin veren çok değişkenli bir yöntemdir" (Mueller, 1996; akt. Şen, 2020). Regresyonda bir tane bağımlı değişken olabilirken yol analizinde birden fazla bağımlı değişken olabilmektedir (Şen, 2020). Yol analizinde örgütsel ikiyüzlülüğün alt boyutları dişsal (exogenous), örgütsel sinizmin alt boyutları ise içsel (endogenous) değişkenler olarak ele alınmıştır.

\section{Bulgular}

Araştırmanın bu bölümünde araştırma kapsamında belirlenen problemlere ilişkin bulgulara yer verilmiştir.

\section{Öğretmenlerin, Örgütsel Sinizm Puanlarnnn Düzeylerine İlişkin Bulgular:} Öğretmenlerin, örgütsel sinizm ölçeğine ilişkin puanlarının ortalama ve standart sapma değerleri boyutlar düzeyinde Tablo 1'de verilmiştir.

Tablo 1. Öğretmenlerin Örgütsel Sinizm Puanlarnın Ortalama ve Standart Sapma Değerleri

\begin{tabular}{lllll}
\hline Boyutlar & N & & $\overline{\mathbf{X}}$ & S \\
\hline Örgütsel Sinizm (Genel) & 378 & 2.51 & .73 \\
Bilişsel Sinizm & 378 & 2.71 & .91 \\
Duyusssal Sinizm & 378 & 1.97 & .88 \\
Davranışsal Sinizm & 378 & 2.80 & .78 \\
\hline
\end{tabular}


Tablo 1 incelendiğinde öğretmenlerin örgütsel sinizm ölçeğinin geneline ilişkin puanlarının aritmetik ortalamasının 2.51; bilişsel, duyuşsal ve davranışsal alt boyutlarına ilişkin aritmetik ortalamasının ise sırasıyla $2.71,1.97$ ve 2.80 olduğu görülmektedir. Öğretmenlerin örgütsel sinizm ölçeğinin geneli ve duyuşsal sinizm alt boyutuna ilişkin puanlarının "Katılmıyorum (1.812.60)" yani düşük düzeyde olduğu; bilişsel ve davranışsal sinizm alt boyutlarına ilişkin puanlarının ise "Kısmen katılıyorum (2.61-3.40)" yani orta düzeyde olduğu görülmektedir.

\section{Öğretmenlerin Örgütsel İkiyüzlülük Puanlarının Düzeylerine İlişkin Bulgu-} lar: Öğretmenlerin, örgütsel ikiyüzlülük puanlarının ortalama ve standart sapma değerleri boyutlar düzeyinde Tablo 2'de verilmiştir.

Tablo 2. Öğretmenlerin Örgütsel İkiyüzlülük Puanlarnın Ortalama ve Standart Sapma Değerleri

\begin{tabular}{llll}
\hline Boyutlar & N & $\overline{\mathrm{X}}$ & S \\
\hline Örgütsel İkiyüzlülük (Genel) & 378 & 2.38 & .61 \\
İçyapı ve Çevre Arasındaki Uyum & 378 & 2.25 & .59 \\
Uygulamalardaki Tutarsızlıklar & 378 & 2.49 & .75 \\
Sözlerin Tutulması & 378 & 2.46 & .74 \\
\hline
\end{tabular}

Tablo 2'ye göre öğretmenlerin örgütsel ikiyüzlülük ölçeğinin geneline ilişkin puan ortalamalarının 2.38; içyapı ve çevre arasındaki uyum, uygulamalardaki tutarsızlıklar ve sözlerin tutulması alt boyutlarının aritmetik ortalamalarının ise sırasıyla 2.25, 2.49 ve 2.46 olduğu görülmektedir. Öğretmenlerin ölçeğin geneli ve alt boyutlarına ilişkin puanlarının "Katılmıyorum (1.812.60)" yani düşük düzeyde olduğu görülmektedir.

\section{Öğretmenlerin Örgütsel Sinizm Puanlarının Demografik Değişkenler Bakı- mından Farklılaşmasına İlişkin Bulgular: Öğretmenlerin bilişsel, duyuşsal ve davranıssal sinizm puanlarının cinsiyet, hizmet süresi ve okul kademesi değişkenlerine göre farklılık gösterip göstermediğini belirlemek için "Iliş̧kisiz Örneklemler için t-Testi" ve "Tek Yönlü Varyans Analizi (ANOVA)" testi ya- pılmıştır. Analiz sonuçları Tablo 3'te gösterilmiştir.}


Tablo 3. Öğretmenlerin Örgütsel Sinizm Puanlarnın Demografik Değişkenlere Göre Farklılaşma Durumu

\begin{tabular}{lllllll}
\hline \multirow{2}{*}{ Boyutlar } & Cinsiyet & \multicolumn{3}{c}{ Hizmet Süresi } & \multicolumn{2}{c}{ Okul Kademesi } \\
\cline { 2 - 7 } & $\boldsymbol{t}$ & $p$ & $F$ & $p$ & $\boldsymbol{F}$ & $p$ \\
\hline Bilişsel Sinizm & -1.69 & .092 & 4.00 & $.008^{*}$ & 1.52 & .208 \\
Duyuşsal Sinizm & .17 & .864 & 1.22 & .277 & 1.08 & .353 \\
Davranışsal Sinizm & .22 & .825 & .44 & .727 & .03 & .994 \\
\hline
\end{tabular}

${ }^{*} p<.05$

Tablo 3 incelendiğinde cinsiyet değişkeni bakımından öğretmenlerin; bilişsel $\left(\bar{X}_{\text {kadın }}=2.64, S S_{\text {kadin }}=.87 ; \bar{X}_{\text {erkek }}=2.81, S S_{\text {erkek}}=.94 ; t(376)=-1.69, p=.092\right)$, duyuşsal $\left(\overline{\mathrm{X}}_{\text {kadnn }}=1.96, S S_{\text {kadnn }}=.87 ; \overline{\mathrm{X}}_{\text {erkek }}=1.97, S S_{\text {erkek }}=.87 ; t(376)=-.17, p=.864\right)$ ve davranışsal ( $\left.\overline{\mathrm{X}}_{\text {kadn }}=2.80, S S_{\text {kadın }}=.81 ; \overline{\mathrm{X}}_{\text {erkek }}=2.78, S S_{\text {erkek }}=.72 ; t(376)=.22, p=.825\right)$ sinizm alt boyut puanları arasında istatistiksel olarak anlamlı farklılık bulunamamiştır.

Hizmet süreleri bakımından ise öğretmenlerin duyuşsal $\left(\overline{\mathrm{X}}_{1-5}=1.87, S S_{1-5}\right.$ $=.84 ; \overline{\mathrm{X}}_{6-10}=2.08, S S_{6-10}=.88 ; \overline{\mathrm{X}}_{11-19}=1.97, S S_{11-19}=.93 ; \overline{\mathrm{X}}_{20+}=1.95, S S_{20+}=.93 ; F=1.292$, $p=.277)$ ve davranışsal $\left(\overline{\mathrm{X}}_{1-5}=2.75, S S_{1-5}=.83 ; \overline{\mathrm{X}}_{6-10}=2.84, S S_{6-10}=.75 ; \overline{\mathrm{X}}_{11-19}=2.77\right.$, $\left.S S_{11-19}=.77 ; \overline{\mathrm{X}}_{20+}=2.86, S S_{20+}=.66 ; F=.44, p=.727\right)$ sinizm alt boyut puanları arasinda istatistiksel olarak anlamlı bir farklılık bulunamazken, bilişsel sinizm alt boyut puanları arasında anlamlı bir farklılık oluşmuştur $[F(3,372)=4.00$, $p<.(05)]$. Farkların hangi gruplar arasında olduğunu belirlemek amacıyla yapılan Scheffe testi sonucunda; 11-19 yıl arası hizmet süresine sahip öğretmenlerin bilişsel sinizm puanlarının ( $\left.\overline{\mathrm{X}}_{11-19}=2.98, S S_{11-19}=1.01\right), 1-5 \mathrm{y}$ 1l $\left(\overline{\mathrm{X}}_{1-5}=2.56, S S_{1}\right.$ ${ }_{5}=.85$ ) arası hizmet süresine sahip öğretmenlerin puanlarından istatistiksel olarak $p<$.(05) anlamlı düzeyde yüksek olduğu görülmüştür.

Son olarak öğretmenlerin görev yaptıkları okul kademeleri bakımından bilişsel ( $\overline{\mathrm{X}}_{\text {anaokulu}}=2.71, S S_{\text {anaokulu }}=.83 ; \overline{\mathrm{X}}_{\text {ilkokul }}=2.65, S S_{\text {ikokul }}=.86 ; \overline{\mathrm{X}}_{\text {ortaokul }}=2.66, S S_{\text {or- }}$ taokul=.90; $\left.\bar{X}_{\text {lise }}=2.92, S S_{\text {lise }}=1.01 ; F=1.52, p=.208\right)$, duyuşsal $\left(\bar{X}_{\text {anaokulu }}=1.99, S S_{\text {anao- }}\right.$ kulu=.62; $\overline{\mathrm{X}}_{\text {ilkokul }}=1.94, S S_{\text {ilkokul }}=.93 ; \overline{\mathrm{X}}_{\text {ortaokul }}=1.90, S S_{\text {ortaokul }}=.86 ; \overline{\mathrm{X}}_{\text {lise }}=2.12, S S_{\text {lise }}=.93$; $F=1.081, p=.353)$ ve davranışsal $\left(\bar{X}_{\text {anaokulu }}=2.81, S S_{\text {anaokulu }}=.74 ; \bar{X}_{\text {ilkokul }}=2.79, S S_{\text {ilko- }}\right.$ kul=.76; $\left.\overline{\mathrm{X}}_{\text {ortaokul }}=2.79, S S_{\text {ortaokul }}=.83 ; \overline{\mathrm{X}}_{\text {lise }}=2.77, S S_{\text {lise }}=.73 ; F=.03, p=.994\right)$ sinizm alt boyut puanları arasında istatistiksel olarak anlamlı bir farklılık bulunamamıştır. 


\section{Öğretmenlerin Örgütsel İkiyüzlülük Puanlarının Demografik Değişkenler} Bakımından Farklılaşmasına İlişkin Bulgular: Öğretmenlerin örgütsel ikiyüzlülük puanlarının cinsiyet, hizmet süresi ve okul kademesi değişkenlerine göre farklılık gösterip göstermediğini belirlemek için yapılan "İlişkisiz Örneklemler İçin t-Testi” ve “Tek Yönlü Varyans Analizi (ANOVA)" testi sonuçları Tablo 4'te gösterilmiştir.

Tablo 4. Öğretmenlerin Örgütsel İkiyüzlülük Puanlarnnın Demografik Değişkenlere Göre Farklılaşma Durumu

\begin{tabular}{lllllll}
\hline \multirow{2}{*}{ Boyutlar } & \multicolumn{2}{l}{ Cinsiyet } & \multicolumn{2}{l}{ Hizmet Süresi } & \multicolumn{2}{l}{ Okul Kademesi } \\
\cline { 2 - 7 } & $\boldsymbol{t}$ & $p$ & $F$ & $p$ & $\boldsymbol{F}$ & $p$ \\
\hline İçyapı ve Çevre Arasındaki Uyum & -2.96 & $.003^{*}$ & 2.23 & .084 & 1.51 & .211 \\
\hline Uygulamalardaki Tutarsızlıklar & -.99 & .324 & 2.61 & .051 & .28 & .841 \\
\hline Sözlerin Tutulması & .40 & .686 & 1.80 & .147 & .58 & .631 \\
\hline
\end{tabular}

${ }^{*} p<.05$

Tablo 4 incelendiğinde cinsiyet değişkeni bakımından öğretmenlerin uygulamalardaki tutarsızlıklar $\left(\overline{\mathrm{X}}_{\text {kadnn }}=2.45, S S_{\text {kadin }}=.72 ; \overline{\mathrm{X}}_{\text {erkek }}=2.53, S S_{\text {erkek}}=.77\right.$; $t(376)=-.99, p=.324)$ ve sözlerin tutulması $\left(\bar{X}_{\text {kadın}}=2.44, S S_{\text {kadın }}=.69 ; \bar{X}_{\text {erkek}}=2.47\right.$, $\left.S S_{\text {erkek }}=80 ; t(376)=-.40, p=.686\right)$ alt boyut puanları arasında istatistiksel olarak anlamlı farklııı bulunamazken, içyapı ve çevre arasındaki uyum alt boyutu puanlarının farklılaştığı belirlenmiştir [t(376) $=-2.96, p<.05]$. Erkek öğretmenlerinin içyapı ve çevre arasındaki uyum boyutu puanlarının $\left(\bar{X}_{\text {erkek }}=2.35, S S_{\text {er- }}\right.$ kek=.67) kadın öğretmenlerin puanlarından $\left(\overline{\mathrm{X}}_{\mathrm{kadı}}=2.17, \mathrm{SS}_{\mathrm{kadın}}=.51\right)$ anlamlı bir biçimde yüksek olduğu görülmüş̧ür.

Hizmet süresi değişkeni bakımından ise öğretmenlerin örgütsel ikiyüzlülük ölçeğinin içyap1 ve çevre arasındaki uyum $\left(\overline{\mathrm{X}}_{1-5}=2.19, S S_{1-5}=.60 ; \overline{\mathrm{X}}_{6-10}=2.29\right.$, $\left.S S_{6-10}=.58 ; \overline{\mathrm{X}}_{11-19}=2.39, S S_{11-19}=.56 ; \overline{\mathrm{X}}_{20+}=2.12, S S_{20+}=.52 ; F=2.23, p=.084\right)$, uygulamalardaki tutarsizlıklar $\left(\overline{\mathrm{X}}_{1-5}=2.39, S S_{1-5}=.72 ; \overline{\mathrm{X}}_{6-10}=2.56, S S_{6-10}=.75 ; \overline{\mathrm{X}}_{11-19}=2.67\right.$, $\left.S S_{11-19=.76 ;} \overline{\mathrm{X}}_{20+}=2.35, S S_{20+}=.78 ; F=2.61, p=.051\right)$ ve sözlerin tutulmasi $\left(\overline{\mathrm{X}}_{1-5}=2.40\right.$, $S S_{1-5}=.69 ; \overline{\mathrm{X}}_{6-10}=2.54, S S_{6-10}=.79 ; \overline{\mathrm{X}}_{11-19}=2.54, S S_{11-19}=.74 ; \overline{\mathrm{X}}_{20+}=2.26, S S_{20+}=.68$; $F=1.80, p=.147$ ) alt boyut puanları arasında istatistiksel olarak anlamlı bir farklilık bulunamamıştır.

Son olarak öğretmenlerin okul kademeleri bakımından örgütsel ikiyüzlülük ölçeğinin içyapı ve çevre arasındaki uyum $\left(\bar{X}_{\text {anaokulu }}=2.15, S S_{\text {anaokulu }}=.45 ; \bar{X}_{\text {il- }}\right.$ kokul $=2.23, S S_{\text {ikokul }}=.60 ; \overline{\mathrm{X}}_{\text {ortaokul }}=2.23, S S_{\text {ortaokul }}=.57 ; \bar{X}_{\text {lise }}=2.37, S S_{\text {lise }}=.65 ; F=1.51$, $p=.211)$, uygulamalardaki tutarsizliklar $\left(\bar{X}_{\text {anaokulu}}=2.51, S S_{\text {anaokulu}}=.58 ; \bar{X}_{\text {ilkokul }}=\right.$ 
2.47, SS ilkokul $\left.=.79 ; \overline{\mathrm{X}}_{\text {ortaokul }}=2.45, S S_{\text {ortaokul }}=.75 ; \overline{\mathrm{X}}_{\text {lise }}=2.55, S S_{\text {lise }}=.74 ; F=.28, p=.841\right)$ ve sözlerin tutulması ( $\overline{\mathrm{X}}_{\text {anaokulu }}=2.48, S S_{\text {anaokulu }}=.59 ; \overline{\mathrm{X}}_{\text {ilkokul }}=2.43, S S_{\text {ilkokul }}=.74 ; \overline{\mathrm{X}}_{\text {or- }}$ taokul= 2.42, $S S_{\text {ortaokul }}=.76 ; \bar{X}_{\text {lise }}=2.55, S S_{\text {lise }}=.75 ; F=.58, p=.631$ ) alt boyut puanlar1 arasında istatistiksel olarak anlamlı bir farklılık bulunamamıştır.

Öğretmenlerin, Örgütsel Sinizm ile Örgütsel İkiyüzlülïk Puanlan Arastndaki İlişkilere Yönelik Bulgular: Araştırmanın bu bölümünde öğretmenlerin örgütsel sinizm ile örgütsel ikiyüzlülük puanları arasındaki ilişkiler incelenmiştir. "Pearson Momentler Çarpımı Korelasyon Katsayısı" tekniğinden yararlanılarak elde edilen sonuçlar Tablo 5'te sunulmuştur.

Tablo 5. Örgütsel Sinizm ile Örgütsel İkiyüzlülük Boyutlarn Arasındaki Korelasyon Sonuçları

\begin{tabular}{lllllll}
\hline Değişkenler & ÖS1 & ÖS2 & ÖS3 & ÖIY1 & ÖIYY2 & ÖIYY3 \\
\hline ÖS1.Bilişsel Sinizm & - & $.60^{*}$ & $.56^{*}$ & $.60^{*}$ & $.72^{*}$ & $.69^{*}$ \\
ÖS2.Duyusssal sinizm & & - & $.53^{*}$ & $.48^{*}$ & $.59^{*}$ & $.56^{*}$ \\
ÖS3.Davranıssal Sinizm & & & - & $.34^{*}$ & $.48^{*}$ & $.46^{*}$ \\
ÖIY1.İ̧yapı ve Çevre Arasındaki Uyum & & & & - & $.61^{*}$ & $.74^{*}$ \\
ÖIY2.Uygulamalardaki Tutarsılıklar & & & & & - & $.73^{*}$ \\
ÖIY3.Sözlerin Tutulması & & & & & & - \\
\hline
\end{tabular}

$N=378{ }^{*} p<.05$

Tablo 5 incelendiğinde iki ölçeğe ilişkin boyutların/değişkenlerin arasında genel olarak orta düzey ve üzerinde pozitif ve anlamlı ilişkilerin bulunduğu görülmektedir ( $p<.05)$. Örgütsel ikiyüzlülük ölçeğinin içyapı ve çevre arasındaki uyum alt boyutu ile örgütsel sinizmin; bilişsel $(\mathrm{r}=.60)$, duyuşsal $(\mathrm{r}=.48)$ ve davranışsal sinizm ( $\mathrm{r}=.34)$ alt boyutları arasında pozitif ve orta düzeyde anlamlı ilişkiler bulunmaktadır. Örgütsel ikiyüzlülük ölçeğinin bir diğer alt boyutu olan uygulamalardaki tutarsızlıklar boyutunun; bilişsel sinizm ( $\mathrm{r}=.72)$ alt boyutuyla yüksek, duyuşsal ( $\mathrm{r}=.59)$ ve davranışsal sinizm $(\mathrm{r}=.48)$ alt boyutlarıyla da orta düzeyde ve pozitif yönlü anlamlı ilişkiler gösterdiği görülmektedir. Son olarak örgütsel ikiyüzlülük ölçeğinin sözlerin tutulması alt boyutunun ise bilişsel ( $\mathrm{r}=.69)$, duyuşsal $(\mathrm{r}=.56)$ ve davranışsal sinizm $(\mathrm{r}=.46)$ alt boyutlarıyla pozitif ve orta düzeyde anlamlı ilişkiler gösterdiği görülmektedir.

Örgütsel İkiyüzlülük ve Örgütsel Sinizm Arasındaki Yol Analizine İlişkin Bulgular: Yol analizi için parametrelerin kestirilmesinde öncelikle en yaygın 
yöntem olarak kullanılan "Maksimum Olabilirlik (ML)" yöntemi kullanılmıştır. ML yönteminin tercih edilme sebebi büyük örneklemlerde etkili, istikrarlı ve yansız parametre kestirimlerine olanak sağlamasıdır (Şen, 2020). Analize geçilmeden önce ML yönteminin kullanılabilmesi için gerekli olan varsayımlar kontrol edilmiştir. Öncelikli olarak araştırmadaki örneklem sayısının, Maksimum Olabilirlik yöntemi için gerekli görülen en az 200 gözlemin (Klein, 2019) üzerinde olduğu görülmüştür. ML yöntemi çok değişkenli normallik varsaydığından boyutların çok değişkenli normallik dağılımı gösterip göstermediği incelenmiştir. Tek değişkenli normallik varsayımının karşılanması çok değişkenli normallik varsayımının da karşılanacağı anlamına gelmez (Çokluk vd, 2014). Her iki ölçeğe ilişkin veriler Mplus girdi dosyası ile analiz edilerek normal dağılım kontrolü yapılmıştır. Her iki sonuç dosyasındaki değerlere göre çarpıklık ve basıklık değerleri manidar bulunmuş $(p<.05)$ ve ilgili normallik varsayımının sağlanamadığ 1 belirlenmiştir. Bu nedenle ML yönteminin daha dirençli bir versiyonu olan ve elde edilen ki-kare değerini olası normal olmayan dağılım durumunda düzelten Yuan-Bentler sağlam ML (MLR) kestirim yöntemi kullanılmıştır (Şen, 2020).

Yapılan yol analizi sonucunda ki-kare değerinin manidar bulunduğu $(p<.05)$, model uyum değerlerin $\chi^{2} / \mathrm{sd}=2.54, \mathrm{CFI}=.93, \mathrm{TLI}=.92, \mathrm{RMSEA}=.06$ ve $\mathrm{SRMR}=.05$ olarak kestirildiği ve değerlerin kabul edilebilir sinırlarda olduğu görülmüştür. Yapılan yol analizine ilişkin standartlaştırılmış yol katsayılarını içeren diyagram modeli Şekil 1'de sunulmuştur.

Yol analizine ait standartlaştırılmış katsayılar incelendiğinde sadece uygulamalardaki tutarsızlıklar değişkeninin örgütsel sinizmin bilişsel, duyuşsal ve davranışsal boyutlarını manidar düzeyde yordadığı görülmüştür $(p<.05)$. Örgütsel ikiyüzlülügünün diğer boyutları olan içyapı ve çevre arasındaki uyum ve sözlerin tutulmasının, örgütsel sinizmin bilişsel ( $\beta$ içyapı-cevre uyumu=.084;

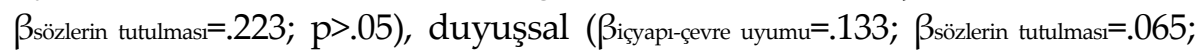

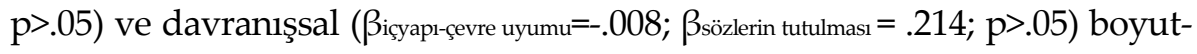
ları üzerinde anlamlı yordayıcılar olmadıkları belirlenmiştir. Bilişsel, duyuşsal ve davranışsal sinizm boyutlarının uygulamalardaki tutarsızlıklar değişkeni açısından standartlaştırılmış regresyon yükleri sırasıyla $0.552,0.485$ ve 0.407 olarak kestirilmiştir. Bu değerler uygulamalardaki tutarsızlık puanlarındaki bir birimlik değişimin bilişsel sinizm üzerinde .55 , duyuşsal sinizm üzerinde .48 ve davranışsal sinizm üzerinde .41 değişime neden olabileceğine 
işaret etmektedir. Uygulamalardaki tutarsızlıklar ve örgütsel sinizmin boyutları arasındaki doğrudan ilişki katsayıları incelendiğinde değişkenler arasinda pozitif ve orta düzeyde ilişki olduğunu göstermektedir ( $\beta$ uygtutarszzlklar-bilissel=.552; $\beta$ uygtutarsızlklar-duyuşsal=.485; $\beta$ uygtutarsızlklar-davranışsal= .407; $p<.01)$. Ayrıca Rkare değeri bağımsız değişkenlerle bilişsel sinizm arasında 0.675 , duyuşsal sinizm arasında 0.424 ve davranısssal sinizm arasında ise 0.352 olarak hesaplanmıştır. Yani örgütsel ikiyüzlülügüü boyutları birlikte bilişsel sinizmdeki varyansın \%67'sini, duyuşsal sinizmdeki varyansın \%42'sini ve davranışsal sinizmdeki varyansın ise \%35'ini açıklamaktadır.

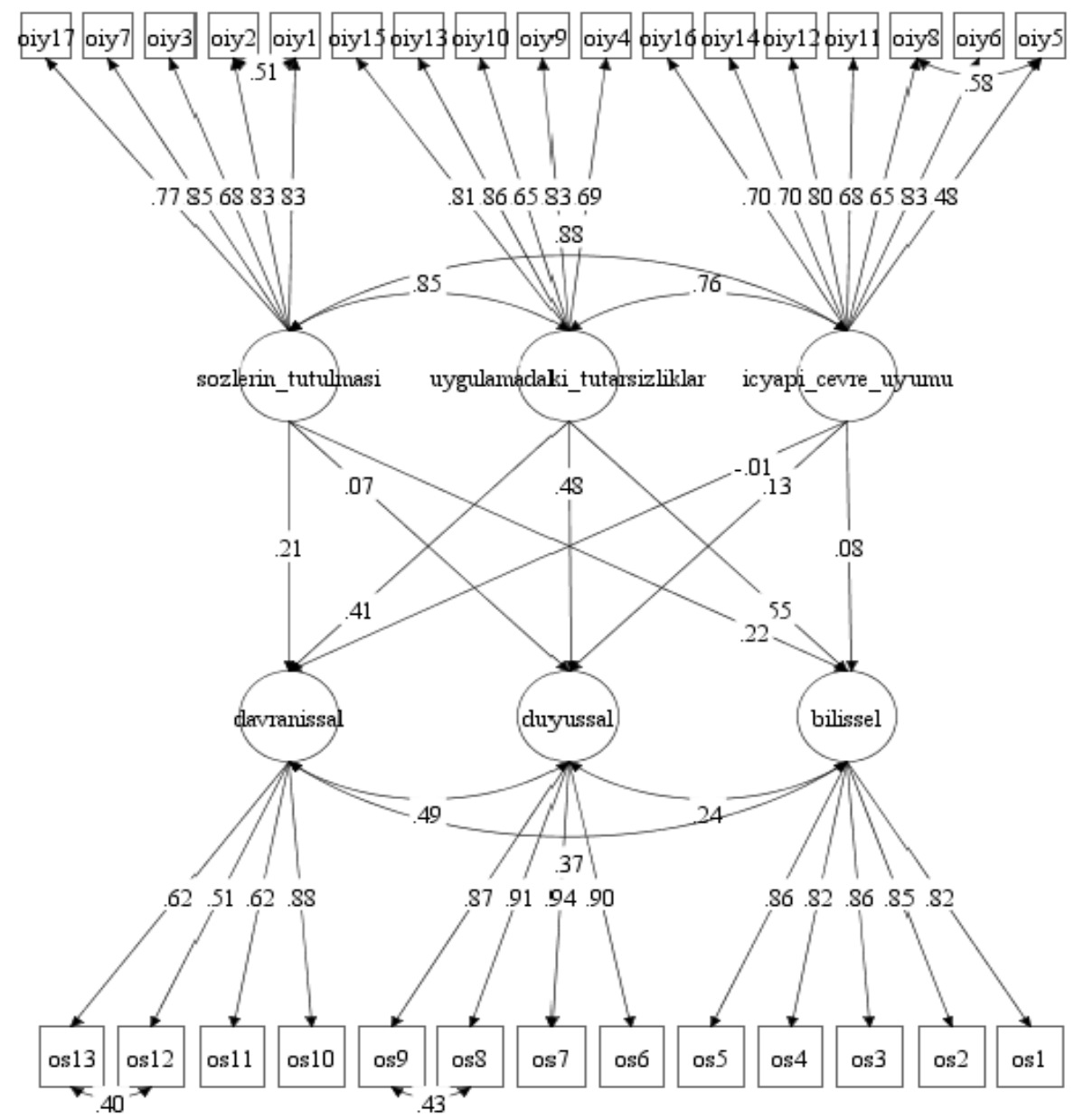

Şekil 1. Standartlaştırılmış Yol Katsayılarını İçeren Diyagram Modeli 


\section{Tartışma ve Sonuç}

$\mathrm{Bu}$ araştırmada temel olarak öğretmenlerin örgütsel sinizm tutumları ile örgütsel ikiyüzlülük algıları arasındaki ilişkilerin incelenmesi amaçlanmıştır. Araştırma sonucunda ulaşılan sonuçlar bölümler halinde ilgili alanyazın 1şığında tartışılmıştır:

Öğretmenlerin, örgütsel sinizm tutumlarının genel olarak düşük düzeyde olduğu sonucuna ulaşılmıştır. Duyuşsal sinizm düzeylerinin bilişsel ve davranışsal sinizme göre daha düşük olduğu belirlenmiştir. Benzer şekilde Gezeroğlu ve Akyavuz'un (2021); Alev' in (2020) çalışmasında öğretmenlerin örgütsel sinizm algiları düşük düzeyde bulunmuştur.

Öğretmenlerin örgütsel ikiyüzlülük algılarının düşük olduğu sonucuna ulaşılmıştır. Benzer şekilde yine öğretmenler üzerine yapılan örgütsel ikiyüzlülük konulu çalışmalarda örgütsel ikiyüzlülük algıları düşük bulunmuştur (Kahveci vd., 2019; Konan ve Taşdemir, 2019). Öğretmenlerin sinizm ve ikiyüzlülük algılarının düşük olması genel olarak okullarda pozitif bir okul ikliminin varlığına işaret ettiği söylenebilir.

Öğretmenlerin, örgütsel sinizm tutumlarının cinsiyetlerine ve görev yap1lan okul kademesine göre anlamlı bir farklılık göstermediği belirlenmiştir. Başka bir çalı̧̧mada da benzer şekilde öğretmenlerin cinsiyet değişkeni ile örgütsel sinizm algıları arasında anlamlı bir fark bulunmamıştır (Ada ve Yarım, 2017). Nitekim araştırmaların büyük çoğunluğunda cinsiyet değişkeninin örgütsel sinizmi etkilemediği sonucuna varılmaktadır (Karacaoğlu ve İnce, 2012, s.80). Hizmet süresi bakımından ise duyuşsal ve davranışsal sinizm tutumları arasında anlamlı bir farklılık bulunamazken, bilişsel sinizm tutumlarının farklılaştığı belirlenmiştir. 11-19 yıl arası hizmet süresine sahip öğretmenlerin bilişsel sinizm tutumlarının 1-5 yıl arası hizmet süresine sahip olan öğretmenlerden daha yüksek olduğu görülmüsştür. Ada ve Yarım (2017) tarafından yapılan çalışmada ise yeni başlamış öğretmenlerin (ilk on yılında olanların) emekliliğe yaklaşmış öğretmenlere göre daha sinik bir tutuma (sinizm davranışlarına) sahip oldukları görülmüştür. Karacaoğlu ve İnce (2012, s.80) ise alandaki çalışmaların hizmet süresi açısından anlamlı bir farklılık göstermediğini ifade etmiştir. Bu çalışma ile diğer çalışmalar birbirinden farklı sonuçlar ortaya koymaktadır. 
Öğretmenlerin örgütsel ikiyüzlülük algılarının görev yapılan okul kademesine ve hizmet süresine göre farklılaşmadığı belirlenmiştir. Örgütsel ikiyüzlülük algılarının, cinsiyet değişkeni bakımından sadece içyapı ve çevre arasındaki uyum alt boyutunda farklılaştığı belirlenmiştir. Erkek öğretmenlerinin içyapı ve çevre arasındaki uyum boyutu puanlarının kadın öğretmenlerin puanlarından anlamlı bir biçimde yüksek olduğu görülmüştür. Fakat, Kahveci vd. (2019) tarafından yapılan çalışmada öğretmenlerin algılarının örgütsel ikiyüzlülük ölçeğinin toplamı, sözlerin tutulması, içyapı ve çevre arasındaki uyum, uygulamalardaki tutarsızlıklar boyutları açısından cinsiyete göre anlamlı fark bulunmamıştır. Kahveci vd. (2019) uygulamalardaki tutarsızlıklar boyutunda 11-20 yıl hizmet süresine sahip öğretmenlerin algılarının 21-üzeri yıl hizmet süresine sahip öğretmenlerden daha yüksek olduğu görülmüştür. Alandaki çalışmaların artmasıyla bu ilişkiler hakkında daha somut yorumlarda bulunulabilir.

Araştırma sonucunda uygulamalardaki tutarsızlıklar ve duyuşsal sinizm arasındaki yüksek korelasyon hariç diğer ikiyüzlülük ve sinizm boyutları arasında orta düzeyde pozitif ve anlamlı ilişkilerin bulunduğu sonucuna ulaşılmıştır. Örgütsel sinizmin boyutlarıyla en yüksek ilişki gösteren örgütsel ikiyüzlülük değişkenin uygulamalardaki tutarsızlıklar boyutu olduğu belirlenmiştir. Korelasyon sonuçları öğretmenlerin; içyapı ve çevre arasındaki uyumsuzluk, uygulamalardaki tutarsızlıklar ve sözlerin tutulmadığı yönündeki algıları arttıkça bilişsel, duyuşsal ve davranışsal sinizm düzeylerinin artabileceğini veya örgütsel ikiyüzlülük algıları azaldıkça örgütsel sinizm düzeylerinin de azalabileceğini göstermektedir. Bu çalışmadaki sonuçlara benzer olarak Kılıçoğlu ve arkadaşları $(2019$, s.20) da örgütsel ikiyüzlülük ölçeğinin bir alt boyutu olan uygulamalardaki tutarsızlıklar boyutu ve örgütsel sinizm alt boyutu bilişsel sinizm arasında yüksek; diğer ikiyüzlülük boyutları ve duyuşsal ve davranışsal sinizm alt boyutları arasında genel olarak pozitif yönde düşük/orta düzeyde anlamlı ilişkiler bulmuştur. Daha detaylı bakılırsa örgütsel ikiyüzlülük ölçeğinin sözlerin tutulması alt boyutunun örgütsel sinizmin bilişsel ve duyuşsal alt boyutlarıyla pozitif yönde orta düzeyde ve davranışsal alt boyutuyla düşük düzeyde anlamlı ilişkiler gösterdiği görülmektedir. İki çalışmanın alt boyutlar bazında ilişkileri incelendiğinde genel olarak büyük bir uyum olduğu görülmektedir.

Yol analizi sonucunda sadece uygulamalardaki tutarsızlıklar değişkeninin örgütsel sinizmin bilişsel, duyuşsal ve davranışsal boyutlarının anlamlı 
yordayıcısı olduğu sonucuna ulaşılmıştır. Örgütsel ikiyüzlülüğünün diğger boyutları olan içyapı ve çevre arasındaki uyum ve sözlerin tutulmasının, örgütsel sinizmin boyutları üzerinde anlamlı yordayıcılar olmadıkları görülmüştür. Uygulamalardaki tutarsızlıklar ile örgütsel sinizmin boyutları arasında pozitif ve orta düzeyde anlamlı ilişkiler bulunmaktadır. Elde edilen değerler uygulamalardaki tutarsızlığın en yüksek oranda bilişsel sinizm olmak üzere sırasıyla duyuşsal ve davranışsal sinizmi orta düzeylerde etkileyebileceğini göstermektedir. Ayrıca uygulamalardaki tutarsızlıklar; bilişsel sinizmdeki varyansın yarıdan fazlasını açıklamakla beraber duyuşsal ve davranışsal sinizmdeki varyansları da önemli oranlarda açıklamaktadır. Bu bulgular doğrultusunda genel ölçek boyutuyla tutarlı olarak Johnson ve O'Leary-Kelly (2003, s.630) ikiyüzlülüğün sinizmi ortaya çıkarabileceğini belirtmiş ve şunları eklemiştir "sinizm yalnızca çalışana verilen belirli vaatlerin ihlal edilmesinden değil, ayn zamanda genel beklentilerin ihlalinden" de kaynaklanabilir. Felming'e (2005, s.290) göre sinizm özellikle sözünü çok tutmayan idareler sayesinde belli bir seviyede oluşur. Kılıçoğlu'na (2017, s.473) göre örgütsel ikiyüzlülük, eğitim örgütlerinde sinizminde içinde olduğu çeşitli patolojik örgütsel davranışlara uygun bir ortam oluşturabilir. Bu açıdan sinizmin öncüllerinden bir tanesinin ikiyüzlülük olduğu söylenebilir.

Çalışma açısından bakıldığında okullarda hissedilen tutarsızlıkların örgütsel sinizmin oluşmasına yol açtığı söylenebilir; bu açıdan diğer çalışmalar okullarda uygulama açısından tutarsızlıklara sebep olan durumları inceleyip sinizm üzerindeki etkisini karma desen çalışmalar ile daha özelde inceleyebilir. Okullarda sinizm ve ikiyüzlülük algılarının oluşması okul çıktılarında olumsuz etkiler oluşturabileceği söylenebilir; bu iki kavramın varlığına ilişkin algının yüksek olduğu gruplar üzerinde bu duruma yol açan temel sorunlar araştırılabilir ve okullarda olumsuz tutumların gelişmemesi için sorun kaynakları haritalandırılabilir. 


\title{
EXTENDED ABSTRACT
}

\section{Examining the Relationship between Organizational Cynicism and Organizational Hypocrisy in Schools}

\author{
Ahmet Göçen - Mehmet Uzun - Ahmet Kaya \\ Harran University-MoNE-KahramanmaraşS Sutcu Imam University
}

Due to the stressful nature of the teaching profession, teachers may experience feelings of burnout and boredom (Sak, 2018). The reasons teachers cite for this problem include a lower level of job satisfaction and a lack of empathic communication and support systems within the school (Göçen, 2019). Along with these reasons, there are newly discussed topics in the literature, such as cynicism and hypocrisy, that inhibit the formation of a healthy work climate. In this respect, schools should take administrative steps to eliminate the sources of mistrust and artificial and unfair treatments that cause cynicism and hypocrisy in the teaching community.

In the most general sense, cynicism is the development of a negative and insecure attitude towards an organization with which a person is affiliated. Organizational cynicism occurs when employees do not trust their institutions or when they feel that they cannot trust their colleagues (Durrah et al., 2019). Hypocrisy in an institution is a concept that includes leaders and teammates who reveal themselves differently among other groups (Konan and Taşdemir, 2019). Organizational hypocrisy in schools means that decisions are easily spoken, but there are times when they are not fulfilled (Kılıçoğlu, 2017, p. 489).

There is a significant relationship between organizational cynicism and organizational hypocrisy (Kılıçoğlu et al., 2019). According to Naus et al. (2007), hypocrisy can be evaluated within the scope of issues such as unreal and unfair treatment, dishonesty, and insincerity that leads to a negative atmosphere in the organization. Those issues, in turn, can give rise to organizational cynicism. From this point of view, one can assume that hypocrisy is a predictor of cynicism. Thus, the researchers decided to examine the relationships between both topics in this study. In addition, teachers' perceptions about these concepts were analyzed according to independent variables such as gender, school type, and length of service. 
This research, which examines the relationship between teachers' organizational cynicism and their perceptions of organizational hypocrisy, is a quantitative study. In this correlational study, which aims to determine the direction of the relationships between the target variables (Akbay, 2019), teachers' perceptions of organizational cynicism and organizational hypocrisy were examined. Relationships between the variables were analyzed by path analysis using structural equation modeling. The research universe for this study consists of 8957 teachers working in public kindergartens and primary, secondary, and high schools in the central districts of the Kahramanmaraş province in the 2020-2021 academic year. The researchers determined that the study sample should be at least 368 teachers for a 95\% confidence level. The data was collected from 378 teachers who filled out the items on cynicism and hypocrisy. There were two scales used for this study. The "Organizational Cynicism" scale developed by Brandes, Dharwadkar, and Dean (1999) was adapted into Turkish by Kalağan (2009). This scale consists of 13 items and three sub-dimensions (cognitive, affective, and behavioral cynicism). The "Organizational Hypocrisy" scale was developed by Kılıçoğlu, Yılmaz-Kılıçoğlu, and Karadağ (2019). This scale consists of 17 items and three sub-dimensions (putting words into practice, compliance between internal structure and the environment, and inconsistency in practices).

In the data analysis, the arithmetic mean and standard deviation values for the variables were checked, the t-test and the one-way analysis of variance (ANOVA) tests were used, along with the post hoc Scheffe test. Correlation analysis was used to determine the relationship between the variables. Path analysis was used to determine the predictive status of independent variables on dependent variables using the mPlus 8 package program. In the path analysis, the sub-dimensions of organizational hypocrisy were considered as exogenous variables, while the sub-dimensions of organizational cynicism were considered as internal (endogenous) variables.

As a result of the data analysis, the researchers concluded that teachers' organizational cynicism perceptions were generally low. Affective cynicism levels were lower than those of cognitive and behavioral cynicism. Similarly, Gezeroğlu and Akyavuz (2021) and Alev (2020) found teachers' perceptions of organizational cynicism to be low. 
It was also discovered that the teachers' perceptions of organizational hypocrisy were low in the sample group. Similarly, in studies on teachers' organizational hypocrisy, the perceptions of organizational hypocrisy were also found to be low (Kahveci et al., 2019; Konan ve Taşdemir, 2019). These results might mean that teachers do not see many cynical or hypocritical features in their schools. Or, the low-level perceptions of hypocrisy and cynicism could be a sign of positive school culture in the sample schools.

The teachers' attitudes about organizational cynicism did not differ significantly according to their gender and the type of school they served. Regarding the length of service, there was no significant difference in the dimensions of affective and behavioral cynicism. The one exception was in the dimension of cognitive cynicism. The teachers with 11-19 years of service had a higher perception of cognitive cynicism than those with 1-5 years of service. That is, the group with higher years of service had more negative cognitive attitude towards their school.

It was determined that the perceptions of organizational hypocrisy differ only in one sub-dimension -- compliance between internal structure and the environment -- in terms of gender. The compliance scores between the school's internal structure and its environment were significantly higher in male teachers than female teachers. This means that males have a more negative attitude towards the school in the sub-dimension of compliance between their school's internal structure and its environment.

A high correlation between inconsistency in practices and cognitive cynicism, this study found. Overall, it also found positive and significant relationships between other dimensions of organizational hypocrisy and cynicism. In addition, it determined that inconsistencies in practices -- the sub-dimension of organizational hypocrisy -- had the highest level of relationship with all dimensions of organizational cynicism. As a result of the path analysis, the study concluded that the dimension of inconsistencies in practices was a significant predictor of the cognitive, affective, and behavioral dimensions of organizational cynicism.

Based on the findings, the study concluded that the inconsistencies felt in schools may support the formation of organizational cynicism. In this respect, future studies could examine the situations that cause inconsistencies in practices in schools. More specifically, they could also examine 
their effect on cynicism with mixed model studies. The formation of cynicism and perceptions of hypocrisy in schools adversely affect school outcomes; thus, the teacher groups with higher levels of cynicism and hypocrisy felt in their schools can be investigated, and problem sources can be mapped so that negative school climates do not develop.

\section{Kaynakça/References}

Abraham, R. (2000). Organizational cynicism: Bases and consequences. Genetic, social, and general psychology monographs, 126(3), 269-292.

Acaray, A. ve Yildirim, S. (2017). The impact of personality traits on organizational cynicism in the education sector. World Journal of Entrepreneurship, Management and Sustainable Development, 13(1), 65-76.

Ada, Ş. ve Yarım, M. A. (2017). İlkokullarda görev yapan öğretmenlerin örgütsel sinizm algıları: Erzurum ili örneği. Igdir University Journal of Social Sciences, 13, 66-98.

Akar, H. (2018). Türkiye'de eğitim örgütlerinde yapılan örgütsel sinizm çalışmalarının içerik analizi. OPUS Uluslararası Toplum Araştırmaları Dergisi, 9(16), 20972127.

Akbay, L. (2019). İlişkisel araştırmalar. Ed. S. Şen ve İ Yıldırım. Eğitimde araştırma yöntemleri içinde, s.117-136. Ankara: Nobel Akademik Yayıncllık

Alev, S. (2020). Okullarda örgütsel sinizmin yordayıcısı olarak lider-üye etkileşimi. Trakya Ĕ̆itim Dergisi, 10(2), 347-360.

Brandes, P., Dharwadkar, R. and Dean, J. W. (1999). Does organizational cynicism matter? employee and supervisor perspectives on work outcomes. Eastern Academy of Management Proceedings içinde (s.150-153). Outstanding Empirical Paper Award.

Büyüköztürk, Ş. (2017). Sosyal bilimler için veri analizi el kitabı. Ankara: Pegem Akademi Yayıncilik.

Çelik, H. E. ve Yılmaz, V. (2014). LISREL 9.1 ile yapısal eşitlik modellemesi. Ankara: Anı Yayıncilik.

Çimen, B. ve Karadağ, E. (2021). Okullarda örgütsel ikiyüzlülük üzerine öğretmen görüşleri. Marmara Üniversitesi Atatürk Eğitim Fakültesi Eğitim Bilimleri Dergisi, 53(53), 227-245.

Çokluk, Ö., Şekercioğlu, G. ve Büyüköztürk, Ş. (2014). Sosyal bilimler için çok değişkenli istatistik SPSS ve LISREL uygulamaları. Ankara: Pegem Akademi Yayıncılık.

Dean, Jr, J. W., Brandes, P. ve Dharwadkar, R. (1998). Organizational cynicism. The Academy of Management Review, 23(2), 341-352. https://doi.org/10.5465/amr.1998.533230. 
Durrah, O., Chaudhary, M. ve Gharib, M. (2019). Organizational cynicism and its impact on organizational pride in industrial organizations. International Journal of Environmental Research and Public Health, 16(7), 1-16. https://doi.org/10.3390/ijerph16071203.

Fleming, P. (2005). Workers' playtime? Boundaries and cynicism in a "culture of fun" program. The Journal of Applied Behavioral Science, 41(3), 285-303.

Gedik, A. ve Üstüner, M. (2019). Öğretmenlerin örgütsel sinizm düzeylerine algıladıkları müdür yönetim tarzının etkisi. Pamukkale Üniversitesi Sosyal Bilimler Enstitüsü Dergisi, 37, 53-68. https://doi.org/10.30794/pausbed.403401.

Gezeroğlu, E. ve Akyavuz, E. K. (2021). Öğretmenlerin örgütsel politika ve örgütsel sinizm algilarının incelenmesi. Muallim Rıfat Eğitim Fakültesi Dergisi, 3(1), 4459.

Göçen, A. (2019). Öğretmenlerin anlam, meslek sürdürme, stres ve tükenmişlik durumlarının ruhsal yaşamları yönünden değerlendirilmesi . Kastamonu Ĕ̆itim Dergisi, 27(4) , 1383-1394. https://doi.org/10.24106/kefdergi.2479.

Higgins, C., Tang, S. ve Stubbs, W. (2020). On managing hypocrisy: The transparency of sustainability reports. Journal of Business Research, 114, 395-407.

Johnson, J. L. ve O'Leary-Kelly, A. M. (2003). The effects of psychological contract breach and organizational cynicism: Not all social exchange violations are created equal. Journal of Organizational Behavior: The International Journal of Industrial, Occupational and Organizational Psychology and Behavior, 24(5), 627-647.

Kahveci, G., Kandemir, İ. K. ve Bayram, S. (2019). Öğretmenlerin örgütsel ikiyüzlülük ile örgütsel adalet algıları arasındaki ilişkinin incelenmesi. Elementary Education Online, 18(2), 788-807. https://doi.org/10.17051/ilkonline.2019.562061.

Kalağan, G. (2009). Araştırma görevlilerinin örgütsel destek algllarn ile örgütsel sinizm tutumları arasındaki ilişki. Yayımlanmamış yüksek lisans tezi. Akdeniz Üniversitesi, Sosyal Bilimler Enstitüsü, Antalya.

Karacaoğlu, K. ve İnce, F. (2012). Brandes, Dharwadkar ve Dean'in (1999) Örgütsel Sinizm Ölçeği Türkçe Formunun geçerlilik ve güvenilirlik çalışması: Kayseri Organize Sanayi Bölgesi Örneği. Business \& Economics Research Journal, 3(3), $77-92$.

Kılıçoğlu, G. (2017). Organizational hypocrisy and integrity in Turkish context: A theoretical analysis. Educational Administration: Theory and Practice, 23(3), 465504.

Kılıçoğlu, G., Kılıçoğlu, D. Y. ve Hammersley-Fletcher, L. (2020). Leading Turkish schools: A study of the causes and consequences of organisational hypocrisy. Educational Management Administration \& Leadership, 48(4), 745-761. https://doi.org/10.1177/1741143218822778. 
Kılıçoğlu, G., Kılıçoğlu, D. Y. ve Karadağ, E. (2019). Do schools fail to "walk their talk"? Development and validation of a scale measuring organizational hypocrisy. Leadership and Policy in Schools, 18(1), 52-82.

Kline, R. B. (2019). Yapısal eşitlik modellemesinin ilkeleri ve uygulaması (Çev. Ed.: Sedat Şen). Ankara: Nobel Akademik Yayıncllk.

Konan, N. ve Taşdemir, A. (2019). Öğretmenlerin örgütsel ikiyüzlülük algıları ile mutluluk düzeyleri algıları arasındaki ilişki. Scientific Educational Studies, 3(2), 132-152.

Naus, F., van Iterson, A. ve Roe, R. (2007). Organizational cynicism: Extending the exit, voice, loyalty, and neglect model of employees' responses to adverse conditions in the workplace.Human Relations, 60(5), 683718. https://doi.org/10.1177/0018726707079198.

Sak, R. (2018). Gender differences in Turkish early childhood teachers' job satisfaction, job burnout and organizational cynicism. Early Childhood Education Journal, 46(6), 643-653.

Seçer, İ. (2013). SPSS ve LISREL ile pratik veri analizi. Ankara: Anı Yayıncllık.

Şen, S. (2020). Mplus ile yapısal eşitlik modellemesi uygulamaları. Ankara:Nobel Akademik Yayıncllık.

Shklar, J. N. (1984). Ordinary vices. Cambridge: Harvard University Press.

Sümer, N. (2000). Yapısal eşitlik modelleri: temel kavramlar ve örnek uygulamalar. Türk Psikoloji Yazlları, 3(6), 49-74.

Tabachnick, B. G. ve Fidel, L. S. (2001). Using multivariate statistics. Massachusetts: Allyn \& Bacon Inc.

Wagner, T., Korschun, D. ve Troebs, C. C. (2020). Deconstructing corporate hypocrisy: A delineation of its behavioral, moral, and attributional facets. Journal of Business Research, 114, 385-394. https://doi.org/10.1016/j.jbusres.2019.07.041

\section{Kaynakça Bilgisi / Citation Information}

Göçen, A., Uzun, M. ve Kaya, A. (2021). Okullarda örgütsel sinizm ile örgütsel ikiyüzlülük arasındaki ilişkinin incelenmesi . OPUSUluslararası Toplum Araştırmaları Dergisi, 18(44), 8001-8024. DOI:10.26466//opus.906933. 